\title{
polyhedra a visual approach
}


UNIVERSITY OF CALIFORNIA PRESS BERKELEY • LOS ANGELES • LONDON 


\title{
polyhedra a visual approach
}

\author{
by Anthony Pugh
}


University of California Press

Berkeley and Los Angeles, California

University of California Press, Ltd.

London, England

Copyright $@ 1976$, by

The Regents of the University of California

ISBN 0-520-02926-7 (clothbound)

ISBN 0-520-03056-7 (paperbound)

Library of Congress Catalog Card Number: 74-27297

Printed in the United States of America 
This volume is dedicated to Dr. R. Buckminster Fuller in recognition of his generous inspiration and encouragement. 
